\title{
THE ANALYSIS OF IMPORTANCE MANAGEMENT STUDENTS TO IMPROVE THE QUALITY OF EDUCATION
}

\author{
Candra Manik \\ Surel: chandramanikunimed@gmail.com
}

\begin{abstract}
This article aims to determine the quality of education in the management of learners. In the era of globalization characterized by fierce competition coupled with the growth and development demands of the democratization of education, accountability, quality and quality assurance demands of the working world, especially the world of education. These conditions require schools and educators and teachers to have reliable quality and as a result the quality assurance process conducted education. Along with the various demands of the quality of government has given rise to various laws and regulations that basically guarantees the quality of educators in managing learners. To improve the competitiveness of graduates as well as other academic products, this among others is achieved through improving the quality of education. Improving the quality of education one can do with good management of learners. With this quality of an education that can be achieved.
\end{abstract}

Key words: Education, Management, Quality

\section{INTRODUCTION}

Management

learners

including one substance management education students occupy a strategic position, because he is a central service education, both in the background and schooling institutions that are outside the institutional background of schooling, directed to students. A program development activity of learners is an area that should be dealt with appropriately. Therefore, the management of these areas should be placed in the category of a special effort to meet the needs of learners, both individuals and groups, including the handling of any problems encountered by learners should be dealt with appropriately.
Therefore, teachers need to be aware that the quality in managing learner is required. Educators and governments need to be aware that the quality of an educational institution can be determined from the workings of members or management of existing personnel within an organization. Improved quality and the quality of an institution needs to be improved so that it can be categorized as an institution that has a quality and a high quality and can compete in the era of globalization.

Indeed it appears the problem of personnel management education, especially in the management of learners. As such, students are often late, noisy students in class during

Dosen Universitas Negeri Medan 
lessons, students are lazy coming school, and these problems cannot be dealt with appropriately by the teacher. Supposedly teachers as educators here must be sensitive and more attention to students, so that students feel comfortable coming to school and in the spirit of the course.

Government and educational institutions need to work together to improve the quality of an educational institution that is in any way concerned teachers in performing or giving a warning if any wrongdoing. Likewise, as a teacher it is necessary to warn students when making mistakes. With the cooperation between teachers and principals quality educational institutions can be achieved.

\section{RESEARCH METHODS}

Moleong (2004:3) suggests a qualitative method as a research procedure that produces descriptive data in the form of words or word of mouth from people and behaviors that can be observed. A qualitative research method is also a research method that is more emphasis on the in-depth understanding of a problem than to see the problems for research generalization. From the above understanding, in this article the researchers using qualitative descriptive method.

This study was conducted on March 3, 2016 in Unimed.

The population of this study is Students of Unimed. And the sample in this study is 30 students of Unimed.

Technique data collection was done by the method of data collection techniques such as interviews are conducted to some students.

\section{DISCUSSION}

The era of globalization requires schools and educators and teachers to have reliable quality and as a result the quality assurance process conducted education. In this case the author is more likely to observe to notice about management education in a school, in particular the management of learners.

In order to achieve organizational goals effectively and efficiently, management in the management of learners should be enabled fully in education, not in spite of the general management functions. Management functions are the basic elements that will always be there and inherent in the management process that will be used as a reference in carrying out activities to achieve a goal that is effective and efficient. An educational institution must have a good quality to compete in the era of globalization is increasingly growing.

Implementation of educational management including:

a. Management learners.

b. Personnel management education

c. Management of educational supplies 
d. Management relationship with the school community, including parents

In this study, the authors focus on attention to the management of learners.

The results of interviews conducted by the authors to students of Unimed about the handling of the problems faced by students, such as students who are lazy to come school. From the results of research conducted showed that $40 \%$ said that the problems faced by students are less dealt with appropriately by the teachers, $25 \%$ stated already, 25\% said not, and $10 \%$ said very less. From the results of research conducted there are many students who stated that handle the management of learners in the problems faced by students are not performing well. Given that the proper management of learners can improve the quality of learners for growing in behavior and behavior and will certainly improve the quality or the quality of the educational institution.

PERCENTAGE OF MANAGEMENT STUDENTS

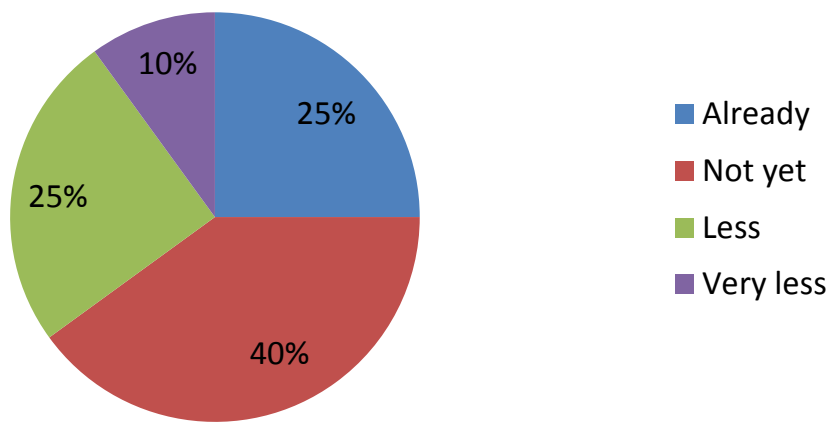

\section{CONCLUSION}

Based on the research, the authors conclude that the management of students in each school that needs to be improved. Given that the management in the management of students occupy a central position in education, if the management of learners performed with both the quality and the quality of education itself will soon be reached. Due to the quality of an educational institution can be seen from the success of teachers and principals personnel in managing the education management in particular learners.

\section{REFERENCES}

Moleong. 2004. Penelitian Kuantitatif dan kualitatif. Jakarta: PT. Gramedia.

Syukir, Asmuni. 2013. Fungsi Manajemen Pendidikan. 
Candra Manik: The Analysis Of Importance ..

http://wwwnengelis.blogspot.c om/2012/03/fungsi-

manajemen-pendidikan.htm.

(Diakses Maret 2016)
Wau, Yasaratodo. 2016. Profesi Kependidikan (Edisi Kedua). Medan: Unimed Press. 